\title{
Russian Revolutions Exhibited: Behind the Scenes
}

\author{
Ekaterina Rogatchevskaia (The British Library)
}

\section{INTRODUCTION}

2017-the centenary year of two Russian revolutions-was marked in Europe, North America, and Russia by a number of academic conferences, publications, talks, public events, and performances. The "silences and noises" made in public discourse and academia in Russia and in the West during this commemorative season have been summarized by Matthew Rendle and Aaron B. Retish. ${ }^{1}$ Public events, programs and exhibitions have been widely reviewed in periodicals, media, social media, and blogs. ${ }^{2}$ Yet art, museum, and

1 Matthew Rendle \& Aaron B. Retish, "Silences and noises: commemorating 1917," Revolutionary Russia 30, no 2 (2018): 151-157.

2 Here is a short list of reviews that represent a wide range of source types (from brief adverts to extensive articles) and opinions, many of them commenting on the exhibition Russian Revolution: Hope, Tragedy, Myth at the British Library: Patrick Burgoyne, "Russian Revolution: Design in a world turned upside down," Creative Review, May 3, 2017, accessed April 6, 2018, https:// www.creativereview.co.uk/russian-revolution-design-world-turned-upside/; Leslie Jones, "Alas, poor Russia," The Quarterly Review, posted on May 2, 2017, accessed April 6, 2018, http:// www.quarterly-review.org/alas-poor-russia/; "Hope, Tragedy, Myths—British Library throws the book at the Russian Revolution," Socialist Worker 2552 (May 2, 2017), accessed April 26, 2018, https://socialistworker.co.uk/art/44524/Hope\%2C+ Tragedy $\% 2 \mathrm{C}+$ Myths+British+Library+throws+the+book+at+the+Russian+Revolution; Alexander Herman, "Russian Revolution(s) at the British Library," Institute of Art and Law, posted April 28, 2017, https://www.ial.uk.com/russian-revolutions-at-the-british-library/; Robert Dex, "British Library puts banned Bolshevik books on show in journey through Russian Revolution," Evening Standard, April 27, 2017, accessed April 6 2018, https://www.standard. co.uk/go/london/arts/british-library-puts-banned-bolshevik-books-on-show-in-journeythrough-russian-revolution-a3525266.html; "Russian Revolution: Hope, Tragedy, Myths," Apollo: The International Art Magazine, accessed April 25, 2018, https://www.apollo-magazine. com/art-diary/russian-revolution-hope-tragedy-myths-british-library/; Miriam Harris, "The British Library's rarely-seen Russian Revolution propaganda posters," Digital Arts, April 28, 2017, accessed April 6, 2018, https://www.digitalartsonline.co.uk/news/illustration/britishlibrarys-rarely-seen-russian-revolution-propaganda-posters/; "Exhibition on Russian Revolution opensatBritishLibrary," XinhuaNet,April28,2017, accessedApril6.2018,http://www.xinhuanet. com/english/2017-04/28/c_136241605.htm; Laura Gozzim, "Russian Revolution: Hope, 
library curators are only now considering putting together reflections of their practices and, by doing so, sharing and analyzing them.

A discussion of the theory of exhibition presentation as a genre, ${ }^{3}$ the specific issues of curatorial styles and (the most relevant issues for me) distinct features of exhibitions in libraries should by all means take place on professional forums for information specialists, librarians, and curators. This article, however, aims at a more general public, offering my reflections on taking part in creating the Russian Revolution: Hope, Tragedy, Myths exhibition at the British Library in my capacity as its lead curator. I will present an account of my experience, to add to the collection of "anecdotal" curatorial stories on "how it was made: from behind the scenes." As the exhibition was a product of extensive collaboration and teamwork, the account presented here is solely based on my personal involvement in the project. I hope that these reflections might be of interest to specialists in Russian studies and Russian history, rather than merely exhibition creators - and, more generally, to exhibition visitors. Sharing curatorial experience and expertise with a wider audience, in my view, might be not only entertaining, but hopefully useful as well. It might be worth mentioning that the British Academy recognizes physical and online exhibitions as one of the primary ways that academic research in the arts and humanities could make

Tragedy, Myths at the British Library," Etcetera, May3, 2017, accessed April 6, 2018, http://www. hamhigh.co.uk/etcetera/art/russian-revolution-hope-tragedy-myths-1-5000629; Aleksandr Kan, "Britanskaia biblioteka: 'Tragediia i mify russkoi revoliutsii," BBC Russian service, May 3, 2017 (video), accessed April 6 2018, https://www.bbc.com/russian/media-39797173; Kristina Moskalenko, “'Russkaia revoliutsiia' v Britanskoi biblioteke: na chto posmotret'," Zima, April 29, 2017, accessed April 6, 2018, https://zimamagazine.com/2017/04/russkayarevolyutsiya-v-britanskoj-biblioteke-na-chto-posmotret/; green_fr, "Russian Revolution v British Library," Livejournal,March 28, 2018, accessed April 6,2018, https://green-fr.livejournal. com/736897.html; "Russkaia revoliutsiiavLondone," Euronews, April29, 2017 (video), accessed April 6, 2018, http://ru.euronews.com/2017/04/29/paper-trail-of-a-revolution-britishlibrary-unveils-centenary-exhibit; "Vystavka k stoletiiu russkikh revoliutsii otkrylas' v Britanskoi biblioteke," RussiaNow.com, April 29, 2017, accessed April 6, 2018, http://russia-now.com/ 206925/\%D0\%B2\%D1\%8B\%D1\%81\%D1\%82\%D0\%B0\%D0\%B2\%D0\%BA\%D0\%B0\%D0\%BA-\%D 1\%81\%D 1\%82\%D0\%BE\%D0\%BB\%D0\%B5\%D 1\%82\%D0\%B8\%D 1 \%8E-\%D1\%80\%D1\%83\%D1\%81\%D1\%81\%D0\%BA\%D0\%B8\%D1\%85-\%D1\%80\%D0\%B5 \%D0\%B2\%D0\%BE\%D0\%BB\%D1\%8E\%D1\%86\%D0\%B8/, etc.

3 This theory is currently in a state of development. See, however, E. Brown and C. Power, Exhibits in Libraries: A Practical Guide (Jefferson, NC: McFarland \& Co, 2006), and several other helpful accounts, such as A. Dutka, S. Hayes, and J. Parnell, "The Surprise Part of a Librarian's Life: Exhibition Design and Preparation Course," College and Research Library News 63 (2002): 19-22; Sean Swanick, Sharon Rankin, and Melinda Reinhart, "Curating Exhibitions in Academic Libraries: Practical Steps," Practical Academic Librarianship: The International Journal of the SLA Academic Division 5 (2015): 1-22, and so forth. 
an impact on the general public, communities, and the UK economy at large. Scholars are encouraged to present the results of their research in accessible ways, a popular exhibition being one of them.

As a result of a series of consultations in 2005, some large museums, galleries, archives, and libraries in the UK received from the Arts and Humanities Research Council (AHRC) the status of Independent Research Organizations (alongside higher education institutions). In 2005/6, the AHRC Museum and Galleries Research Program was launched. ${ }^{4}$ The number of examples of successful collaboration between academia and public sector institutions in creating research-enriched exhibitions is growing, as has been shown in The Impact of AHRC Research and Annual reports. ${ }^{5}$ To facilitate research for the Russian Revolution exhibition, the British Library also set up two Collaborative Doctoral Partnerships (CDPs) ${ }^{6}$ with the University of Nottingham and Queen Mary University of London, as recorded on the AHRC CDP website. ${ }^{7}$ The aim of these projects was to build a small research network that would support curatorial activities around the exhibition, validate ideas and interpretations that would go into the exhibition, benefit from the new research done by CDP students, and provide them with a space for acquiring practical and transferable curatorial skills by actively participating in the exhibition project at every stage. These and similar projects and collaborative programs would, hopefully, instruct a new generation of researchers, who can actively promote an understanding of theories and practices of curating and public engagement.

\section{THE RUSSIAN REVOLUTION EXHIBITION: INTERNAL AND EXTERNAL CONTEXTS}

The exhibition Russian Revolution: Hope, Tragedy, Myths was on show at the British Library from April 28 to August 29, 2017,, and was visited by over

4 "AHRC, Museums and Galleries," accessed April 7, 2018, https://ahrc.ukri.org/funding/ research/museumsandgalleries/.

5 The Impact of AHRC Research, April 2015-March 2016 (file), 12-14, accessed April 7, 2018, https://ahrc.ukri.org/documents/project-reports-and-reviews/the-impact-of-ahrcresearch/2015-16/; Arts and Humanities Research Council Annual Report and Accounts, 2016-17 (file), 4, accessed April 7, 2018, https://ahrc.ukri.org/documents/projectreports-and-reviews/ahrc-annual-report-accounts/arts-and-humanities-research-councilannual-report-accounts-2016-17/.

6 "AHRC Collaborative Doctoral Partnership," accessed April 7, 2018, http://www.ahrc-cdp.org.

7 Katie McElvanney, "Collaborative Doctoral Partnership" (film), accessed April 7, 2018, http://www.ahrc-cdp.org/katie-mcelvanney/.

8 "British Library, What's On," accessed April 6, 2018, https://www.bl.uk/events/russianrevolution-hope-tragedy-myths. 
50,000 people. One hundred and eighty-four physical objects complemented by fifteen audio points, film, and video installations, went on display in the gallery that covers ca. 600 square meters of floor space. Over seventy-five percent of the material presented came from British Library holdings and the rest of the exhibits were borrowed from other institutions or individuals locally, nationally, and internationally. As elegantly put by the author of a very complimentary review in a specialized academic journal,

$[t]$ hroughout its four-month run this definitive exhibition received near universal acclaim with reviewers encouraging the public to come along to the Paccar Gallery in the Library's headquarters on the Euston Road and witness for themselves how the major political events surrounding this seismic revolution had been deftly brought to life. ${ }^{9}$

From the very beginning, we-the four-strong curatorial team in charge (for names, see below) - had the ambition of reexamining our understanding of the Russian Revolution from a modern perspective based on the leading trends in historical research. One of our departure points was what S. A. Smith called "one of the most significant trends in historiography in the new century" - positioning "the 1917 revolutions squarely in a narrative that commences with the outbreak of war in 1914 and ends with the establishment of the Soviet Union in 1922." ${ }^{10}$ Among other works that developed this narrative, ${ }^{11}$ the Russia's Great War and Revolution series ${ }^{12}$ greatly influenced our vision of the project and helped to shape the chronological framework of the exhibition. Setting the scene with prerevolutionary tsarist Russia, the exhibition took visitors through four further sections that told the story of the First World War, the end of the monarchy, the Bolsheviks' military insurrection, the complex civil war, the first months of the Soviet state, the refugee crisis, and the impact of developments in Russia on the world labor movement and politics in general.

9 Robert Henderson, “British Library: 'Russian Revolution. Hope, Tragedy, Myths,” Revolutionary Russia 30, no. 2 (2017): 273.

10 S. A. Smith, "The Historiography of the Russian Revolution 100 Years On," Kritika 16, no. 4 (2015): 734-35, accessed April 6, 2018, doi: 10.1353/kri.2015.0065.

11 See, for example: Joshua A. Sanborn, Drafting the Russian Nation: Military Conscription, Total War, and Mass Politics, 1905-1925 (DeKalb: Northern Illinois University Press, 2003); Peter Gatrell, A Whole Empire Walking: Refugees in Russia during World War I (Bloomington: Indiana University Press, 2005); Jonathan D. Smele, The "Russian" Civil Wars 1916-1926. Ten Years That Shook the World (London: Hurst \& Company, 2015).

12 Slavica Publishers, accessed March 22, 2018, https://slavica.indiana.edu/series/Russia Great_War_Series. 
The display concluded with a short epilogue that showed how the revolution was interpreted and presented in Soviet culture: film, literature, and music.

Two themes were identified as very important for the entire narrative and were present in each section: 1) British perspectives on Russia; and 2) personal accounts of a wide range of people in Russia and beyond. Taking into account that a great number of British visitors might not have profound knowledge of the Russian history and the Russian language, the curators decided that these two themes would help visitors better relate to the exhibition narrative. Some material in the English language, and certain references to well and not so wellknown facts in the British history, on the one hand, and citations from personal accounts of ordinary people, on the other, indeed drew emotional reactions from viewers. We considered this key for people to understand the lessons of the Russian Revolution.

Relations between Russia and Britain were shown: royal family ties-for example, photographs of the Romanovs with Queen Victoria, as well as Tsar Nicholas II with George V, the pair looking almost like identical twins; documents such as a letter written by the British ambassador in Russia, Sir George Buchanan, in which he suggests that the UK refuse refuge to Nicholas II and his immediate family as it could spark unrest; and stories by British journalists, soldiers, and spies. The most popular exhibits in this section (judging by informal feedback) were the sculptor Clare Sheridan's book Russian Portraits, which allowed us to mention her love affair with Lev Kamenev and her conversations with Lenin, while he was sitting for her in 1920, and the memoirs of Paul Dukes-The Story of "ST 25": Adventure and Romance in the Secret Intelligence Service in Red Russia (Fig. 1) — which was opened at a page with numerous photographs of him in disguise. After a public curatorial talk about the exhibition, a gentleman from the audience told me how touched and pleased he was to see this book on display, as Paul Dukes was his parents' acquaintance and visited their home when the gentleman was a small boy.

Another exhibit that led to the most interesting conversation with a visitor was a fur hat on loan from London's Imperial War Museum, which was supplied to British troops in the north of Russia on the advice of polar explorer Sir Ernest Shackleton, who also served with the British expeditionary force in 1919. The object reminded one of the visitors of a story of his grandfather who enlisted to earn money for his wedding and impress the parents of his darling (who was a couple of stairs higher on a social ladder than he was). The Russian campaign was successful for this young man, and the young girl he loved eventually became my interlocutor's grandmother. The "British" theme was essential in 


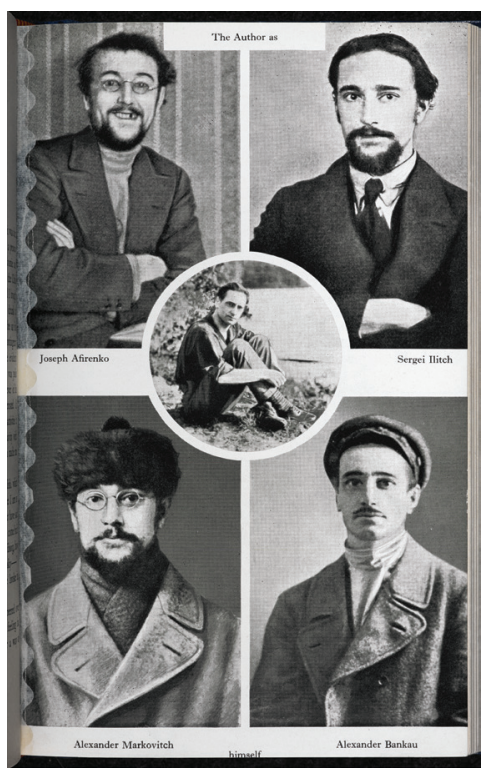

FIGURE 1: Paul Dukes, The Story of "ST 25": Adventure and Romance in the Secret Intelligence Service in Red Russia (London: Casell \& Co, 1938), (C British Library, shelfmark 010290.ff.43)

order to bring in more English-language material, so that visitors could better connect with it, and to give an impression that the Russian Revolution happened much closer to home than British people usually think.

The other recurrent theme was a focus on personal accounts of the people who lived through the revolution. The diary of Meriel Buchanan, Sir George Buchanan's daughter, on loan from the Special Collections of the University of Nottingham Library, was almost the ideal object to display a personal British take on the Russian Revolution.

A combination of chronological and thematic approaches to the narrative put the exhibition in a framework of a fairly traditional history exhibition, which was immediately recognized and noted by reviewers. Although it was easy and tempting to draw parallels with the current political situation, many of which were obvious, this was indeed the area where the curators left room for the audience to treat the exhibition "like a piece of fiction ... weaving an intricate story in which each reader will create their own analogies and interpretations." 13 This move was defined as "wise" by one reviewer, who nevertheless confessed that it was "hard to view the propaganda posters, film footage, news

13 Swanick, Rankin, and Reinhart, "Curating Exhibitions," 9. 
sheets, and photographs without filtering the story of the Russian Revolution through our own current experience of a changing political landscape." ${ }^{14}$ It was also truly rewarding to read in informal reviews that the exhibition managed to remind attentive viewers that "history in the making [was] fluid" and that "the outcome [was] unknown to the participants and the feeling of 'what's going to happen next' [came] through strongly."15

In the centenary year, the exhibition at the British Library had to compete for visitors, critics' stars, and specialists' approval with such visually powerful art shows as the Royal Academy's Revolution: Russian Art 1917-1932, ${ }^{16}$ on the one hand, and TV documentaries and popular histories of the revolution compiled by leading academics and writers, ${ }^{17}$ on the other. In experts' reviews, public responses and professional discussions, the British Library's exhibition was compared to, and put in context with, other art and history shows in Britain and abroad. To name but a few, these were the Tate Modern's Red Star Over Russia: A Revolution in Visual Culture, 1905-1955; ${ }^{18}$ Revolutsiia! Demonstratsiia! Soviet Art Put to the Test at the Chicago Art Institute; ${ }^{19}$ A Revolutionary Impulse: The Rise of the Russian Avant-Garde at the New York MoMA; ${ }^{20}$ Russian Revolution: A Contested Legacy at the International Print Centre, New York; ${ }^{21}$ Royal Fabergé and Radical Russia

14 Jason Hewitt, "Russian Revolution: Hope, Tragedy, Myths" (review), Historia: Magazine of the Historical Writers' Association, May 2, 2017, accessed April 6, 2018, http://www.historiamag.com/hope-tragedy-myths/.

15 Andystan, "Russian Revolution: Hope, Tragedy, Myths" [review], Tripadvisor, July 26, 2017, accessed April 6, 2018, https://www.tripadvisor.co.uk/ShowUserReviews-g186338d187728-r505909650-British_Library-London_England.html\#.

16 “Royal Academy, Revolution: Russian Art 1917-1932," accessed April 6, 2018, https:// www.royalacademy.org.uk/exhibition/revolution-russian-art.

17 See, for example: Sheila Fitzpatrick, "What's Left?," review of October: The Story of the Russian Revolution by China Miéville, The Russian Revolution 1905-1921 by Mark D. Steinberg, Russia in Revolution: An Empire in Crisis, 1890 to 1928 by S. A. Smith, The Russian Revolution: A New History by Sean McMeekin, and Historically Inevitable? Turning Points of the Russian Revolution by Tony Brenton, London Review of Books 39 (March 30, 2017): 13-15, accessed April 6, 2018, https://www.lrb.co.uk/v39/n07/sheila-fitzpatrick/whatsleft; or her own recently published book: Sheila Fitzpatrick, The Russian Revolution (Oxford: Oxford University Press, 2017).

18 “Tate, Red Star over Russia: A Revolution in Visual Culture, 1905-1955," accessed April 6, 2018, http://www.tate.org.uk/whats-on/tate-modern/exhibition/red-star-over-russia.

19 "Art Institute Chicago, Revoliutsiia! Demonstratsiia! Soviet Art Put to the Test," accessed April 6, 2018, http://www.artic.edu/about/press/press-release/revolutsiia-demonstratsiiasoviet-art-put-test.

20 "MoMA, A Revolutionary Impulse: The Rise of the Russian Avant-Garde," accessed April 6, 2018, https://www.moma.org/calendar/exhibitions/1668.

21 “IPCNY, Russian Revolution: A Contested Legacy," accessed April 8, 2018, https://www. ipcny.org/past-exhibitions/2017/12/18/russian-revolution-a-contested-legacy. 
that constituted the Russian Season at the Sainsbury Centre for Visual Arts in Norwich; ${ }^{22}$ The Russian Revolution 1917-1922 at the State Museum of Political History of Russia; ${ }^{23}$ 1917: Romanovs \& Revolution. The End of Monarchy at the Hermitage-Amsterdam Centre; ${ }^{24}$ 1917: Revolution. Russia and Europe, a joint project of the Deutsches Historisches Museum and the Swiss National Museum; ${ }^{25}$ Et 1917 devient révolution at the Bibliothèque de documentation internationale contemporaine (BDIC); ${ }^{26}$ Ecos de los soviets at the Biblioteca Nacional Mariano Moreno de la República Argentina (the National Library of Argentina); ${ }^{27}$ and The Crown Under the Hammer: Russia, Romanovs, Revolution, co-organized by the Hoover Institution Library \& Archives and the Cantor Arts Center. ${ }^{28}$

It is also worth mentioning that the show at the British Library shared many common features (and probably similar issues, too) with the two other successful university library exhibitions on a smaller scale-Caught in the Russian Revolution: The British Community in Petrograd, 1917-1918 (which was on display at the Brotherton Gallery, University of Leeds) ${ }^{29}$ and Red Press: Radical Print Culture from St. Petersburg to Chicago, presented by the University

22 "Sainsbury Centre for Visual Arts, Past Exhibitions, The Russia Season," accessed April 6, 2018, https://scva.ac.uk/art-and-artists/exhibitions/the-russia-season; "Sainsbury Centre for Visual Arts, Past Exhibitions, The Russia Season, Radical Russia”, accessed April 6, 2018, https://scva.ac.uk/art-and-artists/exhibitions/the-russia-season-radical-russia.

23 "The State Museum of Political History of Russia, The Russian Revolution 1917-1922," accessed April 6, 2018, http://www.polithistory.ru/en/visit_us/view.php?id=831.

24 "The State Hermitage Museum, The Hermitage News," accessed April 6, 2018, https:// www.hermitagemuseum.org/wps/portal/hermitage/news/news-item/!ut/p/z1/ pZJNb4MwDIb_ynroEdkkEOgx6hgVXYe6jhVyQRmNKFNJPxbBfv7STtMO-6jW5RA5iq3Hfv2CgByEll1TS9NstdzYdyFYmXLOXDrGJJ4iQx4jSfmM0Dhi8AgCxEbXUCh9DHdVs4KC-khGIykdxqhyPLWqnFBWviMZCZ8IIlWojtmVNjuzhmKtDm1jZK2ulB5itdVGaTNErfqXj5ugG7zHpeuXbgDLc60J-40_HI62XpxLKSwi-ERg5kXIw8WdG9x6Lk 4JLLtG9ZDp7aG1Yi3-KMDkCyG-ia_tEKP5OPRSgpn_HWE5npXzLLq3tZcJfwYa_ HOs5CTrL4uxpmqe93vBrQGOq341kF_igF3bhrR1cnSKpOv7h0lbziLqb2o-GLwBpr_ uyQ!!/dz/d5/L2dBISEvZ0FBIS9nQSEh/?lng=en.

25 "Deutsches Historisches Museum, Exhibitions, 1917. Revolution," accessed April 6, 2018, https://www.dhm.de/en/ausstellungen/1917-revolution.html.

26 "Mission Centenaire 14-18, Exposition 'Et 1917 devient révolution,” accessed May 8, 2018, http://centenaire.org/fr/autour-de-la-grande-guerre/expositions/exposition-et-1917devient-revolution.

27 "Agenda, Ecos de los soviets," accessed May 15, 2018, https://www.bn.gov.ar/agendacultural/ecos-de-los-soviets.

28 Stanford University, Cantor Arts Center, accessed April 6, 2018, https://museum.stanford. edu/exhibitions/crown-under-hammer-russia-romanovs-revolution.

29 "University of Leeds, Events, Caught in the Russian Revolution: British Community in Petrograd," accessed April 6, 2018, https://www.leeds.ac.uk/events/event/4020/caught_ in_the_russian_revolution_the_british_community_in_petrograd_1917-1918. 
of Chicago Library. ${ }^{30}$ All these exhibitions were united by the broad theme of the Russian Revolution, but differed in scope, core material, message, curatorial styles, and many other aspects, including budgets, level of support from hosting organizations, and commercial goals and potentials.

On the other hand, the Russian Revolution: Hope, Tragedy, Myths should be considered in the context of other British Library exhibitions presented in the same space-the Paccar Gallery. The British Library exhibition program is comprised of several temporary displays, including two major exhibitions each year. From 2012, when the British Library introduced exhibition entrance fees in the Paccar Gallery, the program included shows on such diverse topics as Royal Manuscripts: The Genius of Illumination (November 11, 2011-March 13, 2012); Writing Britain: Wastelands to Wonderlands (May 11-September 25, 2012); Mughal India: Art, Culture and Empire (November 9, 2012-April 2, 2013); Propaganda: Power and Persuasion (May 17-September 17, 2013); Georgians Revealed: Life, Style and the Making of Modern Britain (November 8, 2013-March 11, 2014); Comics Unmasked: Art and Anarchy in the UK (May 2-August 19, 2014); Terror and Wonder: The Gothic Imagination (October 3, 2014-January 20, 2015); Magna Carta: Law, Liberty, Legacy (March 13-September 1, 2015); West Africa: Word, Symbol, Song (October 16, 2015-February 16, 2016), Shakespeare in Ten Acts (April 15-September 6, 2016); and Maps and the 20th Century: Drawing the Line (November 4, 2016-March 1, 2017).

Of those on this list, the Russian Revolution exhibition is one of only three exhibitions - the other two being Mughal India and West Africa-that was based primarily on British Library collections of foreign material. According to visitor numbers and income generated, it did well and is placed in the same cluster with Terror and Wonder, Comics Unmasked, and Propaganda and Maps, although it is definitely not in the league of commercial superstars like Magna Carta and Harry Potter: A History of Magic (October 20, 2017-February 28, 2018) that went on show straight after the Russian Revolution exhibition.

Ninety-five percent of identified visitors ${ }^{31}$ to the Russian Revolution exhibition came from the United Kingdom. People aged sixty-five and over formed the largest demographic group, followed by people between fifty-five

30 "The University of Chicago Library, News, Red Press: Radical Print Culture from St. Petersburg to Chicago," posted on August 28, 2017, accessed April 6, 2018, http://news.lib.uchicago. edu/blog/2017/08/28/red-press-radical-print-culture-from-st-petersburg-to-chicago/.

31 The report was done by the British Library marketing team based on a representative group of ca. 1,500 people or three percent of all visitors. 
and sixty-four, and then young people in their mid-twenties and thirties. Among identified visitors fifty-two percent were women. When asked about the emotions they felt during their exhibition visit, many visitors named "inspiration," "surprise," "excitement," "empowerment," and so forth; but the most popular by far was "sadness." The exhibition was visited by a large number of academics and education professionals. On average, they rated it higher than people without a specialist background, and enjoyed it more than the general culturally curious audience, who, according to the evaluation research, had slightly different expectations of what they came to see (that is, the material proved to be more distressing than enjoyable). Therefore, the exhibition scored slightly lower in terms of the expectation criteria when compared with other similar exhibitions at the British Library. Few than usual numbers of the exhibition visitors (excluding academics and educators) said that the exhibition was "better than expected."

Having looked at this and other data, I would carefully suggest two most plausible primary explanations for the results achieved by the exhibition. Although the Russian Revolution is still perceived as relevant, especially as part of the centenary reexamination of the First World War, the exhibition required from visitors some effort to learn previously unknown facts and process information that shared little with to their own cultural experience. The display did not fully resemble the expected visual feast of Russian avant-garde artworks that are associated with this historic period, and the predominant feeling of sadness did not correlate well with an anticipation of having a good time in the process of a cultural or learning experience. As the lead curator, I take full responsibility for both of these "faults," although I do not regret my conscious decision not to shy away from the complexity of the story and to refrain from giving the exhibition a look that would be dominated by powerful Soviet propaganda. I am very grateful that my co-curator Susan Reed, the two CDP students Katie McElvanney and Mike Carey, and the exhibition team shared my view and provided enormous support that helped me to deal with the difficulties in achieving our goals. Analysis of feedback is useful for understanding the audience and its needs, but I believe that it is equally important to get across the message based on professional expertise. The ultimate goal of modern exhibitions is to engage with the audience without patronizing them by simplification or alienating them by complexity. As we can see from formal evaluation, informal feedback, and professional reviews, the exhibition held slightly more appeal to those with some background knowledge or strong interest in the subject, but also managed to move and surprise visitors of all backgrounds. 


\section{VISUALIZING HISTORY}

It is generally expected and agreed that an exhibition should be an entertaining way of learning. However, I would also stress that exhibitions transform certain aspect of the visitors' interests, attitudes, or values, ${ }^{32}$ which, hopefully, the British Library's Russian Revolution exhibition achieved by appealing to visitors on an emotional, as well as intellectual, level. Long gone are the days when " $[\mathrm{t}]$ he visitor was conceptualized as a more or less absorbent sponge encountering the expert knowledge provided by the museum," 33 and we (the curatorial team) intentionally encouraged visitors to respond to the ambiance of the exhibition gallery, shaped by its 3D and graphic design. The importance of design in a museum (and even more so in a library gallery) is impossible to underestimate. The design throughout the gallery organizes the area, giving the narrative its spatial interpretation by creating logical pauses, helping visitors navigate their way through the display, and highlighting items that deserve special attention. In the design tender brief for the Russian Revolution exhibition we specifically stressed that we would like to avoid the easy route of using the kind of radical and abrupt transitions typical of Constructivist aesthetics (a popular choice among many designers tasked with a visual representation of the Russian Revolution). Instead, we visualized our exhibition as a mood piece that would create a true emotional atmosphere of "hope, tragedy, and myth." The response from the company Hara Clark was very convincing, as they suggested using different sources of visual inspiration for each section: the grandeur of an imperial palace created by plus red curtains; an Ikea chandelier; a minimalistic and symbolic display of two large maps of the Russian Empire; and a first edition of the Communist Manifesto (that looked tiny placed between among these other elements. These items gradually gave way to images of the streets of St. Petersburg and Moscow where the struggle for power was happening. The space then opened up into a wide area inspired by a vision of a forest clearing associated with Boris Pasternak's Dr Zhivago. Continuity was supported by what we called the "red line," a concept that evolved significantly in the course of the project. Initially, we imagined the red line as a highlighting structure that would accentuate the exhibition's changing focus from the main socio-political narrative to the personal stories of individuals-ordinary people who lived through these extraordinary times (Fig. 2).

32 Barry Lord et al., eds., Manual of Museum Exhibitions (Lanham, MD: Rowman \& Littlefield, c. 2014), 13.

33 S. Macdonald, "Interconnecting: museum visiting and exhibition design," CoDesign 3 (2007): 150 . 


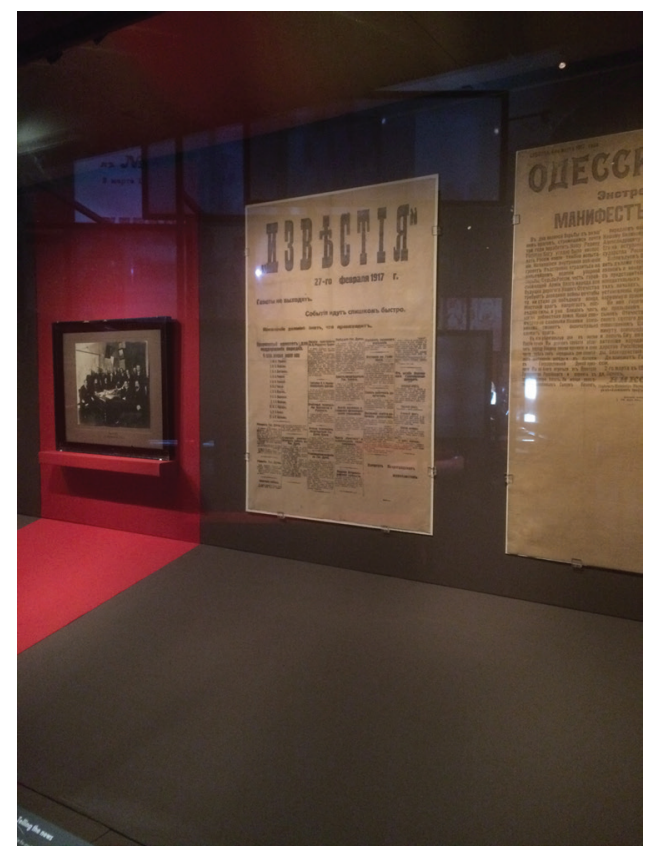

FIGURE 2: An example of the red line. The Photograph of Ministry of Transport officials, 1917 (Loan, Special Collections, Leeds University Library, LRA MS 716) was accompanied by an excerpt from telegram to Tsar Nicholas sent by Chairman of the State Duma Mikhail Rodzianko, March 12 and 13 (February 27 and 28), 1917 and lurii Lomonosov's diary entry, March 1, 1917.

While researching for the exhibition, we realized that in the last two decades, scholarship on the Russian revolution had engaged more with social theories and produced a number of groundbreaking works on grassroots movements, gender roles, regional variations, non-Russian territories within the Russian Empire, socio-cultural practices, and everyday life. ${ }^{34}$ Translating these themes into an exhibition was not an easy task. I initially struggled to present the collection material-primarily print books, newspapers, and ephemera - in such a way that they could be interpreted within the new scholarly frameworks and through recent theoretical lenses. The idea of giving actors in, and witnesses of, the revolution their individual voices by quoting

34 See the following overviews of the current state of research: Smith, "The Historiography of the Russian Revolution 100 Years On"; and R. Wade, "The Revolution at One Hundred: Issues and Trends in the English-Language Historiography of the Russian Revolution of 1917," Journal of Modern Russian History and Historiography 9 (2016): 9-38, accessed April 6, 2018, doi: 10.1163/22102388-00900003. 
personal accounts, diaries, and letters was implemented in two parts-visual and audio-both of them becoming an integral design feature of the exhibition. Each exhibition section contained one or two items placed against the red background with an additional label — a short extract that would refer to some personal story, such as a letter from the young Vladimir Ulianov (Lenin) to his mother, recollections of the railway engineer Iurii Lomonosov about stopping Tsar Nicholas's personal train from entering Petrograd (which subsequently led to the tsar's abdication), or reminiscences of an imperial theatres' actress about how the last royal gifts that were presented to her colleague just days before the revolution. Extracts from a list of horrific executions performed by the Cheka (Soviet secret police, the KGB's predecessor), a passage from Isaak Babel"s collection of short stories Konarmiia (The Red Cavalry), and a poem from a magazine printed by Czech legionnaires in Siberia also belong to the same category of objects.

For practical reasons, all these objects were displayed in stand-alone or perimeter cases, but could not constitute a visual red line on their own. The designer suggested that, visually, the red line would become a light frame structure with transparent fabric of different shades of red, stretched within the frames. It was then decided that these pieces of fabric would bear prints of photographs from the period. Seventy-six photographs and ten quotations were selected from various sources, and printed on fabric and panels. Many of the prints had a dividing line across them as a symbol of fracture and distress. Audio points were placed on the same frame structure to reinforce the significance of the red line. This gave visitors an opportunity to listen to oneor two-minute extracts from personal letters and diaries of ordinary Russian and British people (one notable exception was the famous British author H. G. Wells). Russian texts were translated into English especially for the exhibition and recorded by professional actors.

We did not particularly plan it this way, but when the selection of extracts was finalized, we noticed that almost all of them were accounts by young people. My personal favorite was the diary of a fourteen-year-old boy, who in his diary first described a demonstration mourning Lenin's death which he watched on his way from school, and then noted that back home he had to study German with his school friend Kirill.

To find just eight short extracts, we had to read dozens of books. Fortunately, the online project Prozhito.org has made many texts more accessible, and the entire database highly searchable. According to the evaluation report, commissioned by the British Library, only thirty percent of visitors 
engaged with the audio, but of those who did, over seventy percent admitted that this significantly increased their understanding of the exhibition.

Powerful and naturally blended into the fabric of the exhibition as they may have been, very few exhibits could be presented purely as objects held in the British Library. Only on three occasions was the text in the label quoted from the item exhibited on the red line. On other occasions, the texts were taken from sources that were not visually appealing and would not be interesting to look at. The available material required significant extra backing (design, translation, changing its physical format, such as an audio recording of written diaries, and so forth) before it could support our argument on the importance of everyday life and ordinary people in the story of the revolution. Despite representing the nature of the British Library as a home for written texts, these exhibits could hardly excite our visitors about our collections and holdings. However, the red line as a design solution created the much needed atmosphere of uneasiness and tension, and contributed significantly to the overall emotional impact of the exhibition narrative on the viewers.

Visualization can be very important, not only as a pure design feature, but also as something that plays a special role in the display of objects in cases. I would argue that the issue of such presentation is more acute for library exhibitions, compared to exhibitions in museums and art galleries. For example, there is often a discrepancy between the importance of content, on the one hand, and the relevant item's poor visual appeal, on the other. Using visually rich items multiple times is also practically difficult and problematic. In the first section of the exhibition, one of the star items was the coronation album of Nicholas II-a beautiful book with was created not only as an encyclopedia of coronation festivities and rituals, but as a valuable material object, a symbolic representation of authority and power of the Russian monarchy. ${ }^{35}$ Several prominent Russian artists were tasked with documenting the festivities, and the book contains high-quality reproductions of their work.

For the purpose of the exhibition, the book could be opened on almost any page to show almost any of those illustrations, but I thought that the best

35 See: M. V. Ryzhanok, "Khudozhestvennoe oformlenie koronatsionnogo alboma Nikolaia II 1896 goda," Izvestiia Rossiiskogo gosudarstvennogo pedagogicheskogo universiteta im. A. I. Gertsena 175 (2015): 138-151. 
use of the it would be to focus on the story of the Khodynka stampede that happened during the festivities. This focus allowed us not only to show the life of the Romanovs, but to introduce the theme of how Nicholas II frequently mishandled critical situations. The picture by Vladimir Makovskii, although tense and emotional, shows the crowd before the tragedy, and therefore requires a great deal of explanation. To let viewers have a little bit more time for appreciating the scale of the tragedy, we needed to keep them in front of the display for slightly longer than it is normally required to glance at the picture of a crowd. Two other objects loaned to us were displayed next to the album to visually expand the story. One of them was a souvenir mug that the people in the picture were waiting to get as a free gift (and for which hundreds lost their lives), and a goblet from an imperial set with Tsar Nicholas's initials. A private collector who helped us to source the mug kept warning me that it was not rare, but for me this was not very relevant, as in this display the object played a very special role. Although the name of the person who had got it (and probably escaped death in the stampede) was lost in history, the juxtaposition of these three items built a powerful visual image and helped visitors expand it into a full visual story (Fig. 3).

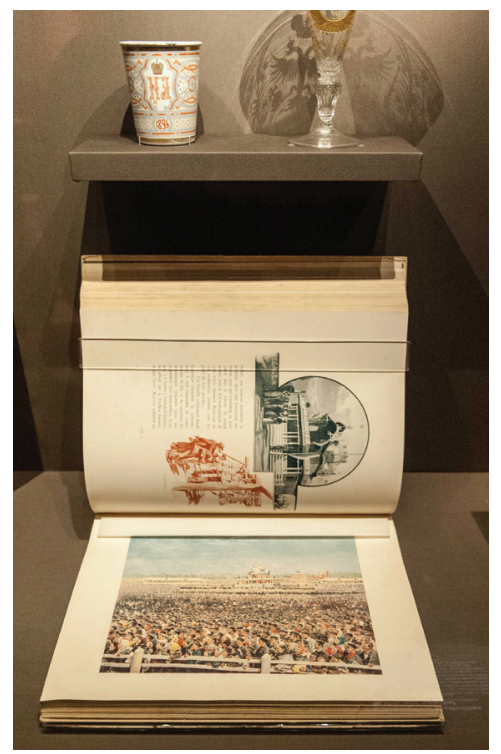

FIGURE 3: Les Solennités du saint couronnement (St. Petersburg, 1899), (c) British Library, shelfmark L.R.25.c.20, displayed with a souvenir coronation cup, private loan, and a wineglass engraved with the Cipher of Nicholas II, loan, British Museum, 1994, 0508.1. 


\section{ONE-HUNDRED-WORD STORIES}

In a times when even official bodies and senior politicians express themselves in 280-character tweets, it is hardly surprising that stories can be told in a hundred words, as we see from a newly published anthology. ${ }^{36}$ Exhibition as a genre of presentation that tells a story through exhibition labels is very much in accord with the fast speed of information acquisition and processing today. It is expected that an average visitor will spend between sixty to ninety minutes in an exhibition gallery. However, those with some previous knowledge of the subject, or an interest in it, according to anecdotal evidence, spent between two and three hours there. In line with British Library in-house exhibition guidelines, our curatorial team aimed to write section panels in no more than 150 words, while the labels' word limit was 100 . For the purpose of this article, I calculated that in total we offered our visitors about 24,500 words of nonlinear and fragmented text. Good label writing is one of the most discussed questions in the curatorial community and is subject to numerous guidelines and handbooks. I would single out Dany Louise's Interpretation Matters Handbook. ${ }^{37}$ Leaving the quality of label writing out of the scope of this article, the point to be made here is the tension that any curator feels for the entire duration of the project from scoping to interpretation. This is the tension between the space of the text that curators think they need and the physical space of a gallery and the time which visitors are willing to spend in it. For me, this spatial and temporal tension manifested in a conflict between the accuracy of factual presentation and the necessity of a comprehensive and linear narrative, on the one hand, and the need to simplify, streamline, and break the narrative into pieces, on the other. For example, quoting figures or dates that could be obtained from different sources was a minefield, as options to indicate the discrepancies were minimal or sometimes just impossible to convey in the given space.

The choice of terminology also often required a considerable amount of research. For example, some authors referred to the armed forces of Southern Russia, while some referred to the armed forces of South Russia. The emphasis was made on the general geographical area, rather than "south of the country," and we had to make an informed decision to be prepared to reply to feedback, in case our visitors questioned our preferences for one school of history over another. In one comment, a visitor pointed out that we only mentioned

36 Grant Faulkner et al. (eds.), "Nothing Short of: Selected Tales from 100 Word Story.org," Outpost19, 2018.

37 Dany Louise, Interpretation Matters Handbook (London: Black Dog Publishing, 2015). 
Norway as a place of diplomatic service of Alexandra Kollontai, missing out her terms in Mexico and Sweden, to which I had to reply that any more complete information was precluded by the word limit.

\section{CURATOR'S CHOICE}

The curatorial team was often asked, for marketing and press purposes, which exhibits were our personal favorites. To be entirely honest, I favored some items of the story for their discovery, selection, and the effort put into explaining their role in the show, such as a photograph of soldiers reading Tsar Nicholas's abdication manifesto in a popular magazine Solntse Rossii (Sun of Russia) (Figs. 4 and 5). Unfortunately, the British Library does not have the April, 1917, issue of this magazine, and we had to order a digital image of its cover from the National Library of Russia. Both of these images, the reading soldiers and the magazine cover, ended up in the red line frames and were placed so high up that few visitors likely registered them.

Sometimes an item would cost curators several sleepless nights or the shocking realization that they were struggling to say anything sensible and interesting about it. This was precisely the case with an original photograph that we requested on loan from a private collector. The photograph depicted one of the many demonstrations that happened in Petrograd in spring 1917. This was a fascinating object — an image taken by a famous Russian photographer in an original print. However, I was failing miserably in the task of explaining to visitors why they should engage with it, until I found out what exactly

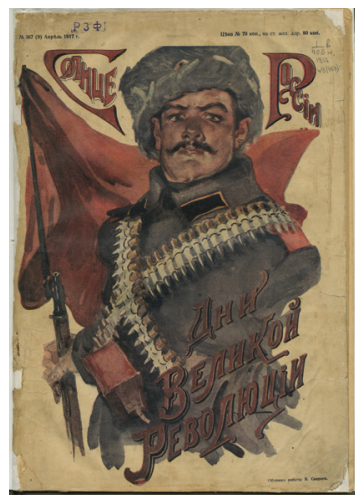

FIGURE 4: Solntse Rossii

(Sun of Russia) (April 1917).

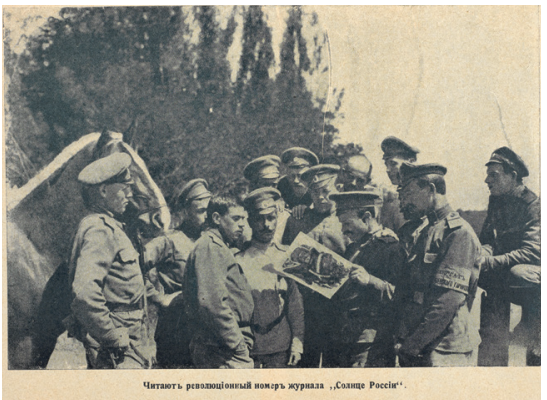

FIGURE 5: Group of soldiers reading the same issue of Solntse Rossii; photograph from Voina i revoliutsiia (War and Revolution), Petrograd, 1918, (c) British Library, shelfmark X.802/4756. 
the image depicted and established a personal connection between the artist and the event he captured, making it the focus of the following exhibition label:

This photograph by Karl Bulla (1855-1929) shows the demonstration of Estonian soldiers on 8 April (26 March) 1917, who saw the fall of the monarchy as an opportunity to get autonomy for Estonia. Several days later the Provisional Government issued a decree that united all Estonian regions into one administrative and autonomous area with its assembly and executive bodies. Bulla's wife was Estonian, so his interest in this was also personal. He soon handed over his business to his sons and left for Estonia for good.

For my own personal and nostalgic reasons, my favorite objects were several banknotes that had been in circulation in 1917-1922 and belonged to my grandmother. On the accompanying label, I wrote:

One of the Provisional Government's first acts was to order a new issue of banknotes. In spring 1917, five and ten ruble notes were issued, using the design of 1909, with simplified serial numbers. New designs were also created. Printed in America, some notes only reached Russia in 1918. Twenty and forty ruble notes were issued in August 1917. They were of simplified design and level of protection. Although generally known as "kerenky" (the Kerensky money), they were mostly printed by the Soviet government, and remained in circulation until 1922 [Fig. 6]. Growing hyperinflation meant that printed strips of banknotes were no longer cut, so that people exchanged long ribbons of money.

The biggest hit of this exhibition, however, mentioned almost in every review, blog, or interview, was an admission request to become a reader at the British Museum Library from one Jacob Richter-one of Vladimir Ulianov's

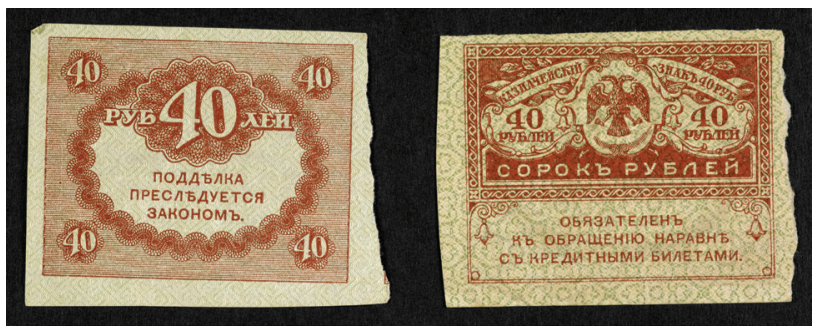

FIGURE 6: Banknotes, private loan. 
pseudonyms. If there could ever exist a perfect exhibit, this was it: a handwritten document by one of the most famous men in the world, related to the place where it was kept and put on display (the British Library); still slightly veiled in mystery (although solved), as it was not signed in the person's real name; and easily accessible, because it was inscribed in English in a clear cursive (Fig. 7). This was truly the most popular object among visitors, and definitely the one that most of them were surprised to see, and therefore remembered. This object gave viewers an opportunity to reconstruct a curious episode of the private life of Lenin, and remind themselves that this had been happening just in local streets. Stories of individuals and the British theme were successfully combined in the exhibit and this was recognized by the audience.

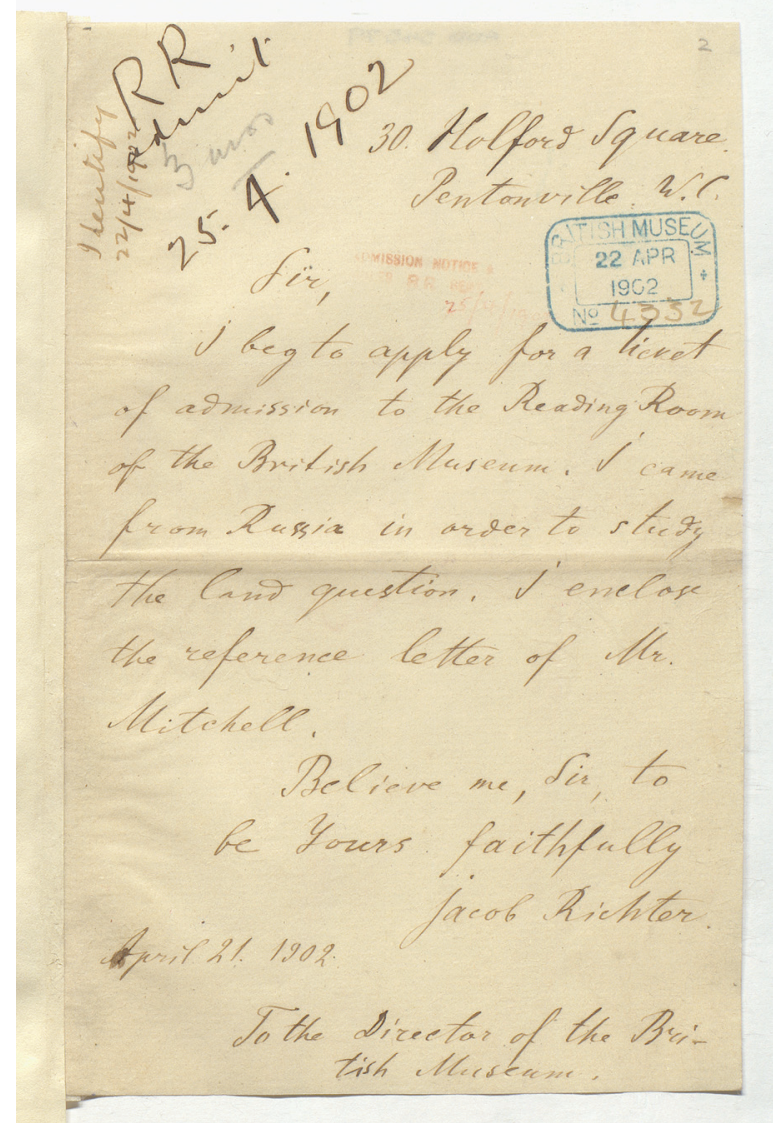

FIGURE 7: Marx-Lenin Papers: correspondence and other papers concerning the use of the Reading Room at the British Museum, (C) British Library, shelfmark Add.MS.54579. 
For nearly all the visitors with a Russian background, the most impressive exhibits were the White propaganda posters (Fig. 8) - a totally hidden and surprising part of the civil war narrative.

Another example of an object that had an immediate appeal for some visitors, was an absolutely unique item that I found in the British Library manuscript collection. It was a hand-lettered wall newspaper, or a placard newspaper, made by Soviet women in 1927, which we displayed in the section "Brave New World." The vogue for such newspapers emerged in Soviet Russia due to a shortage of print facilities and materials. Wall newspapers were meant to disseminate official and local news, and very soon became a powerful propaganda tool. Small communities (or, collectives) of coworkers or co-students formed editorial boards and periodically issued wall newspapers. This one was issued by a local women's committee in Yalta. It contains reports on their joint achievements, amateur poetry, and stories intended to inspire and promote new communist values. The "women-delegates," as they called themselves, described their everyday life in simple words and propaganda clichés. Portraits of the women, who created the wall paper-its editorial board-are painted in watercolors in the middle. Despite their similar look-they are all typical

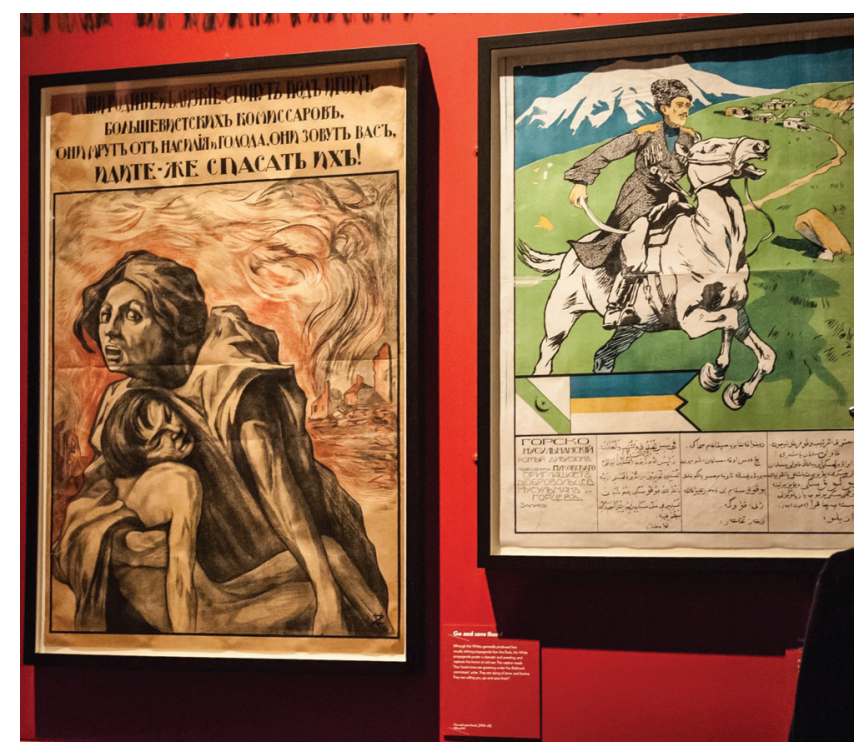

FIGURE 8: Two posters on display: “Go and save them!” (1918-20?), (C) British Library, shelfmark 1856.g.8.(17) and “Mountain-dwellers and Muslims, enlist” (1920), (c) British Library, shelfmark 1856.g.8.(30). 
of Soviet propaganda poster, in that they feature identical red scarves tied at the back - the wallpaper was a real message from the past directly from these young women. Those visitors who had personal experience in making wallpapers from growing up in the Soviet Union or in the Eastern Bloc were very much inclined to extend their imagination and see these women as individuals in flesh and blood. If I had had information on the provenance of this item, this could have created an even more powerful personal story, but without it the wallpaper was probably more difficult to contextualize for British visitors, as they did not usually have an experience of wallpaper making and could not fully relate to it. At the same time, the point that wallpapers did not mean to survive, and even less be kept in foreign libraries, was always much appreciated by visitors, as was the humor of the picture of a multitasking girl in the lower corner. From anecdotal evidence, visitors were happy to engage with, and express sympathy towards, a Soviet girl who was cooking, cleaning, and writing an article for a wallpaper at the same time (Fig. 9).

\section{CONCLUSIONS}

Quite a few themes, thoughts, and anecdotes have been left out of this account. Looking through the special literature available for, and written by, exhibitions curators in the arts, museums, and libraries, I can see that there is still no standard way of documenting such an ephemeral genre as exhibitions. Reading catalogues and books to accompany exhibitions is not the same as experiencing an exhibition as a visitor. Similarly, from a curatorial perspective, writing catalogues is a very different type of work from creating an exhibition. I hope that this discussion of the importance of documenting exhibitions will result

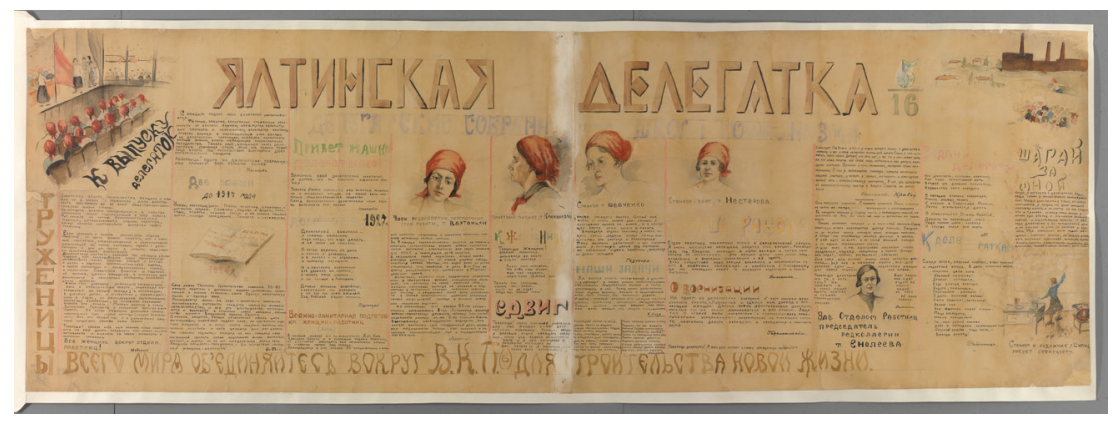

FIGURE 9: The Yalta Female Delegate, hand-lettered wall newspaper, 1927, (c) British Library, shelfmark Add.MS.57556. 
in a more open exchange of curatorial practices and thinking, problems and their solutions, reflections and analyses within the curatorial community and beyond. I would like to believe that the Russian Revolution centenary year was a cultural and historical event that will create a forum for such an exchange.

\section{Bibliography}

"AHRC Collaborative Doctoral Partnership." Accessed April 7, 2018. http://www.ahrc-cdp.org. Andystan. "Russian Revolution: Hope, Tragedy, Myths" (review). TripAdvisor, July 26, 2017. Accessed April 6, 2018. https://www.tripadvisor.co.uk/ShowUserReviews-g186338d187728r505909650-British_Library-London_England.html\#.

Art Institute Chicago. Revoliutsiia! Demonstratsiia! Soviet Art Put to the Test. Accessed April 6, 2018. http://www.artic.edu/about/press/pressrelease/revolutsiia-demonstratsiia-soviet-art-put-test.

Arts and Humanities Research Council Annual Report and Accounts, 2016-17. Accessed April 7, 2018. https://ahrc.ukri.org/documents/project-reports-and-reviews/ahrc-annual-reportaccounts/arts-and-humanities-research-council-annual-report-accounts-2016-17/.

BritishLibrary. What's On.Accessed April 6, 2018, https://www.bl.uk/events/russian-revolutionhope-tragedy-myths.

Brown, E., and C. Power. Exhibits in Libraries: A Practical Guide. Jefferson: McFarland \& Co, 2006. Deutsches Historisches Museum. Exhibitions. 1917: Revolution. Accessed April 6, 2018. https:// www.dhm.de/en/ausstellungen/1917revolution.html.

Dutka, A., S. Hayes, and J. Parnell. “The Surprise Part of a Librarian's Life: Exhibition Design and Preparation Course." College and Research Library News 63 (2002): 19-22.

Faulkner, Grant, Lynn Mundell, and Beret Olsen (eds.). "Nothing Short Of: Selected Tales from 100 Word Story.org." Outpost 19, 2018.

Fitzpatrick, Sheila. The Russian Revolution. Oxford: OUP, 2017.

. "What's Left?" Review of October: The Story of the Russian Revolution by China Miéville, The Russian Revolution 1905-1921 by Mark D. Steinberg, Russia in Revolution: An Empire in Crisis, 1890 to 1928 by S.A. Smith, The Russian Revolution: A New History by Sean McMeekin, Historically Inevitable? Turning Points of the Russian Revolution by Tony Brenton. London Review of Books 39 (March 30, 2017): 13-15. Accessed April 6, 2018. https://www. lrb.co.uk/v39/n07/sheila-fitzpatrick/whats-left.

Gatrell, Peter. A Whole Empire Walking: Refugees in Russia During World War I. Bloomington: Indiana University Press, 2005.

Henderson, Robert. “British Library: 'Russian Revolution. Hope, Tragedy, Myths.” Revolutionary Russia 30, no. 2 (2017): 273-275. Accessed April 20, 2018. doi: 10.1080/09546545.2017.1 384142 .

Hewitt, Jason. "Russian Revolution: Hope, Tragedy, Myths" (review). Historia: Magazine of the Historical Writers' Association, May 2, 2017. Accessed April 6, 2018. http://www.historiamag. com/hope-tragedy-myths/. 
IPCNY. Russian Revolution: A Contested Legacy. Accessed April 8, 2018. https://www.ipcny.org/ past-exhibitions/2017/12/18/russian-revolution-a-contested-legacy.

Louise, Dany. Interpretation Matters Handbook. London: Black Dog Publishing, 2015.

Macdonald, S. "Interconnecting: museum visiting and exhibition design." CoDesign 3 (2007): 149-62. Accessed April 6, 2018. doi: 10.1080/15710880701311502.

Lord, Barry, et al., eds. Manual of museum exhibitions. Lanham: Rowman \& Littlefield, c. 2014.

McConnell Simpson, Helen. "Moved by Conflict: Individualising the History of Bristol during the First World War." Social History in Museum 40 (2016): 10-18.

McElvanney, Katie. Collaborative Doctoral Partnership. Accessed April 7, 2018. http://www. ahrc-cdp.org/katie-mcelvanney/.

MoMA. A Revolutionary Impulse: The Rise of the Russian Avant-Garde. Accessed April 6, 2018. https://www.moma.org/calendar/exhibitions/1668.

Morrow, Daniel. “For Us They Fell': A First World War Community. Commemoration Project and Exhibition." Social History in Museum 40 (2016): 4-9.

Read, Christopher. War and Revolution in Russia, 1914-22. Basingstoke: Palgrave Macmillan, 2013.

Rendle, Matthew, and Aaron B. Retish. "Silences and noises: commemorating 1917." Revolutionary Russia 30, no. 2 (2018): 151-157. Accessed April 20, 2018. doi: 10.1080/09546545.2017.1 411225.

Royal Academy. Revolution: Russian Art 1917-1932. Accessed April 6, 2018. https://www. royalacademy.org.uk/exhibition/revolution-russian-art.

Ryzhanok, M. V. "Khudozhestvennoe oformlenie koronatsionnogo al'boma Nikolaia II 1896 goda." Izvestiia Rossiiskogo gosudarstvennogo pedagogicheskogo universiteta im. A. I. Gertsena 175 (2015): 138-151.

Sainsbury Centre for Visual Arts. Past Exhibitions. The Russia Season. Accessed April 6, 2018. https://scva.ac.uk/art-and-artists/exhibitions/the-russia-season and https://scra.ac.uk/artand-artists/exhibitions/the-russia-season-radical-russia.

Sanborn, Joshua A. Drafting the Russian Nation: Military Conscription, Total War, and Mass Politics, 1905-1925. DeKalb: Northern Illinois University Press, 2003.

Slavica Publishers. Accessed March 22, 2018. https://slavica.indiana.edu/series/Russia_Great_ War Series.

Smith, S. A. "The Historiography of the Russian Revolution 100 Years On." Kritika 16, no. 4 (2015): 733-49. Accessed April 8, 2018. doi: 10.1353/kri.2015.0065.

Stanford University. Cantor Arts Center. Accessed April 6, 2018. https://museum.stanford. edu/exhibitions/crown-under-hammer-russia-romanovs-revolution.

Swanick, Sean, Sharon Rankin, and Melinda Reinhart. "Curating Exhibitions in Academic Libraries: Practical Steps," Practical Academic Librarianship: The International Journal of the SLA Academic Division 5 (2015): 1-22.

Tate. Red Star Over Russia: A Revolution in Visual Culture, 1905-1955. Accessed April 6, 2018. http://www.tate.org.uk/whats-on/tate-modern/exhibition/red-star-over-russia. 
Terwey, Michael. "Social History Curatorship in Crisis." Social History in Museum 39 (2015): 4-7.

The Impact of AHRC Research, April 2015-March 2016. Accessed April 7, 2018. https://ahrc. ukri.org/documents/project-reports-and-reviews/the-impact-of-ahrc-research/2015-16/.

The State Hermitage Museum. The Hermitage News. Accessed April 6, 2018. https:// www.hermitagemuseum.org/wps/portal/hermitage/news/newsitem/news/2017/ news_15_17/!ut/p/a0/04_Sj9CPykssy0xPLMnMz0vMGjzOL9HR3NDI2dDbzcvQ3MD BzdDYz8HX2NjN1dzfQLsh0VAbzyHw!/.

The State Museum of Political History of Russia. The Russian Revolution 1917-1922. Accessed April 6, 2018. http://www.polithistory.ru/en/visit_us/view.php?id=831.

The University of Chicago Library. News. Red Press: Radical Print Culture from St. Petersburg to Chicago. Posted on August 28, 2017. Accessed April 6, 2018. http://news.lib.uchicago.edu/ blog/2017/08/28/red-press-radical-print-culture-from-st-petersburg-to-chicago/.

The University of Leeds. Events. Caught in the Russian Revolution: British Community in Petrograd. Accessed April 6, 2018. https://www.leeds.ac.uk/events/event/4020/caught_in_the_russian_revolution_the_british_community_in_petrograd_1917-1918.

Wade, R. "The Revolution at One Hundred: Issues and Trends in the English Language Historiography of the Russian Revolution of 1917." Journal of Modern Russian History and Historiography 9 (2016): 9-38. Accessed April 6, 2018. doi: 10.1163/22102388-00900003. 